\title{
Pengaruh ROA, ROE, NPM Terhadap Pertumbuhan Laba (Studi Empiris Perusahaan Sektor Perbankan Tahun 2017- 2019)
}

\author{
Fitri Handayani ${ }^{1}$, Mohamad Zulman Hakim ${ }^{2}$, Dirvi Surya Abbas ${ }^{3}$ \\ Universitas Muhammadiyah Tangerang1,2,3 email korespondensi: \\ firhand20@gmail.com
}

\begin{abstract}
Abstrak: Tujuan dari penelitian ini adalah untuk mengetahui pengaruh secara simultan maupun parsial variabel Return on Assets, Return on Equity dan Net Profit Margin terhadap pertumbuhan laba. Periode penelitian yang digunakan yaitu tahun 2017-2019. Populasi dalam penelitian ini adalah laporan keuangan perusahaan yang tergabung dalam subsektor Perbankan yang terdaftar di Bursa Efek Indonesia sebanyak 44 perusahaan. Penelitian ini menggunakan teknik Purposive Sampling sehingga diperoleh 26 sampel perusahaan, dengan menggunakan data sekunder berupa data laporan keuangan tahunan perusahaan subsektor Perbankan periode 2017-2019. Teknik analisis data yang digunakan dalam penelitian ini adalah analisis regresi linear berganda dengan bantuan Eviews. Hasil penelitian ini menunjukkan bahwa secara simultan Return on Assets dan Return on Equity tidak berpengaruh terhadap pertumbuhan laba sedangkan Net Profit Margin berpengaruh terhadap pertumbuhan laba pada perusahaan subsektor Perbankan yang terdaftar di Bursa Efek Indonesia.

Kata kunci: Return on Assets, Return on Equity, Net Profit Margin dan Pertumbuhan Lab
\end{abstract}

Berdasarkan dari UU Nomor 10 Tahun 1998, secara garis besar tujuan perbankan Indonesia adalah menunjang pelaksanaan pembangunan nasional dalam rangka meningkatkan pemerataan, pertumbungan ekonomi, dan stabilitas nasional ke arah peningkatan kesejahteraan rakyat. Dari tujuan tersebut maka perbankan (bank) di Indonesia harus menjalankan tugas dan fungsinya dengan baik dan didasarkan atas asas demokrasi ekonomi. Bank yang sehat adalah bank yang dapat menjaga dan memelihara kepercayaan masyarakat, dapat menjalankan fungsi intermediasi, dapat membantu kelancaran lalu lintas pembayaran serta dapat dipergunakan oleh pemerintah dalam melaksanakan fungsi-fungsi tersebut diharapkan dapat memberikan pelayanan yang baik kepada masyarakat serta bermanfaat bagi perekonomian secara keseluruhan (Abdullah, 2003:38).

Teori sinyal (signaling theory) pertama kali diperkenalkan oleh Spence di dalam penelitiannya yang berjudul Job Market Signaling. Spence (1973) mengemukakan bahwa di dalam pasar ketenagakerjaaan selalu terjadi informasi yang asimetris, sehingga Spence membuat suatu kriteria sinyal untuk dapat memperkuat pengambilan keputusan dalam perekrutan tenaga kerja di perusahaan. Sinyal tersebut berupa latar belakang pendidikan, pengalaman kerja, ras, jenis kelamin, dan kepribadian. Adanya kriteria ini didasarkan pada suatu ketidakpastian tentang kemampuan produktivitas karyawan. Model signaling Spence dikembangkan oleh Leland dan Pyle tahun 1977. Mereka mengatakan bahwa adanya asimetri informasi antara dua pihak, yaitu pihak di dalam perusahaan dan diluar perusahaan. Investor akan menginvestasikan 
dananya apabila mendapatkan sinyal terkait informasi tentang perusahaan, sinyal tersebut bisa berupa pembayaran dividen, pengumuman pendapatan, dan sebagainya (Manurung, 2012:114).

Dua bank Badan Usaha Milik Negara (BUMN), yakni PT Bank Rakyat Indonesia (Persero) Tbk (BRI) dan PT Bank Negara Indonesia (Persero) Tbk (BNI) tumbuh melambat sepanjang 2019. BRI tercatat meraup laba bersih Rp34,41 triliun pada 2019 atau tumbuh 6,15\% dibandingkan 2018. Pertumbuhan laba itu melambat signifikan dibandingkan kenaikan laba tahun 2018 yang mencapai 11,6\%. Serupa, BNI juga mencatatkan pertumbuhan laba di 2019. BNI membukukan laba bersih sebesar Rp15,38 triliun pada 2019, naik tipis 2,5\% dibandingkan tahun sebelumnya yaitu Rp15,02 triliun. Meski meningkat, pertumbuhan laba BNI jauh lebih lambat dibandingkan tahun lalu yakni 10,3\%.

Perlambatan pertumbuhan laba dua bank pelat merah disebabkan perlambatan pertumbuhan kredit. BRI merekam pertumbuhan penyaluran kredit sebesar 8,44\% dari Rp843,6 triliun menjadi Rp908,88 triliun. Tahun lalu, BRI mampu mencatat pertumbuhan kredit hingga dua digit yakni $14,1 \%$. Sementara itu, kredit segmen ritel dan menengah tumbuh $12,08 \%$ dari Rp240,57 triliun menjadi Rp269,64 triliun, kredit segmen konsumer naik 7,38\% dari Rp130,84 triliun menjadi Rp140,50 triliun. Hanya kredit segmen korporasi yang turun $0,74 \%$ dari Rp192,45 triliun menjadi Rp191,02 triliun. Untuk BNI, pertumbuhan kredit tercatat sebesar 8,6\% dari Rp512,78 triliun pada 2018 menjadi Rp556,77 triliun pada 2019. Serupa, pertumbuhan kredit BNI juga lebih rendah dari pertumbuhan kredit tahun lalu sebesar $16,2 \%$. Penyaluran kredit ke segmen kredit kecil tercatat tumbuh $14,2 \%$ dari $\mathrm{Rp} 66,06$ triliun pada 2018 menjadi Rp75,4 triliun pada 2019. Pertumbuhan yang menonjol terjadi pada penyaluran Kredit Usaha Rakyat (KUR) yang meningkat dari Rp16 triliun pada 2018 menjadi Rp17,7 triliun pada 2019. Sementara itu, penyaluran kredit ke segmen kredit konsumer naik 7,7\% dari Rp75,4 triliun menjadi Rp85,87 triliun. Lalu, kredit BNI juga tersalurkan ke segmen kredit koporasi dengan kenaikan 9,8\%. Pinjaman infrastruktur menjadi salah satu prioritas dalam bisnis korporasi ini, salah satunya adalah proyek jalan tol.

Sayekti dan Sumarno (2015) Return on Assets merupakan rasio untuk mengetahui kemampuan perusahaan memperoleh laba dalam hubungannya dengan total aktiva. Semakin besar Return on Assets mengindikasikan keuntungan yang diperoleh perusahaan atas aset juga meningkat sehingga menambah kemampuan perusahaan dalam meningkatkan laba. Sebaliknya, semakin kecil Return on Assets mengindikasikan keuntungan atas aset mengalami penurunan, sehingga akan mengurangi kemampuan perusahaan untuk meningkatkan pertumbuhan laba.. Beberapa penelitian terdahulu mencoba mengaitkan faktor kondisi keuangan perusahaan terhadap pertumbuhan laba. Penelitian yang dilakukan Ravasadewa dan Fuadati (2018), menyatakan Return on Asset (ROA) berpengaruh Positif terhadap Pertumbuhan Laba. Jika terdapat peningkatan pada rasio Return on asset (ROA) maka akan 
meningkatkan terjadinya aktifitas pertumbuhan laba, hasil rasio yang tinggi menunjukkan bahwa perusahaan berusaha untuk meningkatkan pendapatan atau penjualan sehingga pertumbuhan laba juga meningkat. Dengan adanya usaha perusahaan untuk meningkatkan tingkat pendapatan maupun penjualan maka pertumbuhan laba akan meningkat dengan sendirinya melalui tingkat pendapatan atau penjualan yang diperoleh perusahaan dalam satu periode. Sebaliknya, Safitri dan Mukaram (2018), menyatakan Return on Asset (ROA) berpengaruh negatif terhadap pertumbuhan Laba. sedangkan penelitian yang dilakukan Nino Sri Purnama Yanti (2017), menyatakan Return on Asset (ROA) tidak berpengaruh terhadap pertumbuhan Laba.

Berdasarkan hasil penelitian diatas dapat diumuskan sebuah hipotesis yaitu :

H1 : Diduga Return on Asset berpengaruh terhadap pertumbuhan laba.

Safitri dan Mukaram (2018) Return on Equity merupakan rasio yang digunakan untuk mengukur tingkat pengembalian atas investasi yang telah ditanamkan oleh pemilik modal pada perusahaan. Semakin tinggi Return on Equity menunjukkan semakin efisien perusahaan menggunakan modal untuk menghasilkan laba bagi pemilik modal sehingga dapat meningkatkan pertumbuhan laba perusahaan. Sebaliknya, semakin rendah Return on Equity menunjukkan perusahaan tidak efisien dalam menggunakan modal dan semakin kecil tingkat keuntungan yang diperoleh oleh pemilik modal.. Penelitian Febrianty dan Divianto (2017), membuktikan Return On Equity (ROE) berpengaruh Positif terhadap Pertumbuhan Laba. Sebaliknya, penelitian yang dilakukan Ravasadewa dan Fuadati (2018), menyatakan Return On Equity (ROE) berpengaruh negatif terhadap pertumbuhan Laba. Sedangkan penelitian yang dilakukan Djamereng dan Priliyadi (2020), menyatakan Return On Equity (ROE) tidak berpengaruh terhadap pertumbuhan Laba. Berdasarkan hasil penelitian diatas dapat diumuskan sebuah hipotesis yaitu :

H2 : Return On Equity berpengaruh terhadap pertumbuhan laba.

Beny Hidayat (2015) Net Profit Margin dapat diinterpretasikan sebagai tingkat efisiensi perusahaan, yaitu sejauh mana kemampuan perusahaan dalam menekan biaya-biaya yang ada di perusahaan. Semakin tinggi Net Profit Margin menunjukkan semakin efektif suatu perusahaan dalam menjalankan operasinya sehingga akan menghasilkan laba yang tinggi. Sebaliknya, semakin rendah Net Profit Margin akan menghasilkan laba yang rendah pula.. Penelitian Djannah dan Triyonowati (2017), menyatakan Net Profit Margin (NPM) berpengaruh Positif terhadap Pertumbuhan Laba. Sebaliknya, penelitian yang dilakukan

Agustininingsih dan Soebroto,S.E.,M.M.,serta Rakim,S.E.,M.E. (2019), menyatakan Net Profit Margin (NPM) berpengaruh negatif terhadap pertumbuhan Laba. Sedangkan penelitian yang dilakukan Nino Sri Purnama Yanti (2017), penelitian menunjukkan Net Profit Margin 
(NPM) tidak berpengaruh terhadap pertumbuhan Laba. Berdasarkan hasil penelitian diatas dapat diumuskan sebuah hipotesis yaitu :

H3: Net Profit Margin berpengaruh terhadap pertumbuhan laba.

\section{METODE}

Penelitian ini menggunakan pendekatan kuantitatif dengan bentuk asosiatif. Penelitian ini dilakukan untuk mengetahui pengaruh ROA, ROE, NPM terhadap pertumbuhan laba. Penelitian ini dilakukan pada sektor Perbankan yang terdaftar di Bursa Efek Indonesia (BEI) tahun 20172019. Pengambilan sampel dalam penelitian ini menggunakan metode purposive sampling, yaitu sampel yang dipilih dengan pertimbangan tertentu. 1). Perusahaan perbankan yang terdaftar di BEI pada tahun 2017-2019. 2). Perusahaan perbankan yang telah mempublikasikan laporan keuangan per 31 Desember tahun 2017-2019. 3). Perusahaan perbankan yang memiliki laporan keuangan dari tahun 2017-2019 tidak rugi secara berturut turut karena penelitian ini bertujuan untuk melihat pertumbuhan laba.

Dalam penelitian ini, teknik analisis data yang digunakan adalah analisis regresi data panel dengan bantuan software pengolah data statistic yaitu Eviews 9.0. berikut metode analisis data yang digunakan :

\section{Uji Statistik Deskriptif}

Menurut Ghozali (2013:17) statistik deskriptif memberikan gambaran atau deskripsi suatu data yang dilihat dari nilai rata-rata (mean), standar devisiasi, varian, maksimum, minimum, sum, range, kurtosis dan skewness (kemencengan distribusi).

\section{Estimasi Regresi Data Panel}

Menurut Sriyana (dalam Eksandy, 2018:21-26), model regresi data panel terbagi menjadi 3, yaitu:
a. Common Effects Model (CEM)
b. Fixed Effect Model (FEM)
c. Random Effect Model (REM)
Teknik Pemilihan Model Regresi Data Panel

\section{Uji Chow}

Hipotesis dalam Uji Chow :

$\mathrm{HO}$ : Model mengikuti Common Effect Model (CEM)

$\mathrm{Ha}$ : Model mengikuti Fixed Effect Model (FEM)

\section{Uji Hausaman}

Hipotesis dalam Uji Hausaman :

HO : Model mengikuti Random Effect Model (REM)

$\mathrm{Ha}$ : Model mengikuti Fixed Effect Model (FEM) 


\section{Uji Langrage Multiplier}

Hipotesis dalam Uji Langrage Multiplier:

$\mathrm{HO}$ : Model mengikuti Common Effect Model (CEM)

$\mathrm{Ha}$ : Model mengikuti Random Effect Model (REM)

\section{Uji Asumsi Klasik}

Menurut (Eksandy, 2018:77), Perlu atau tidaknya uji asumsi klasik tergantung pada hasil pemilihan estimasi model regresi. Dalam regeresi data panel model yang berbasis Ordinary Least Square (OLS) adalah Common Effect Model (CEM) dan Fixed Effect Model (FEM), dengan demikian perlu dilakukan uji asumsi klasik. Sebaliknya, apabila persamaan regresi lebih cocok menggunakan Random Effect Model (REM), maka tidak perlu dilakukan uji asumsi klasik.

\section{Uji Hipotesis}

Uji F digunakan untuk menjelaskan apakah semua variabel bebas yang dimasukkan ke dalam model secara bersama-sama mempunyai pengaruh terhadap variabel terikat atau tidak, apabila uji $F$ tidak berpengaruh maka penelitian tidak dapat dilanjutkan karena model penelitian tidak dapat menjelaskan adanya hubungan antar variabel independen dengan dependen.

Perbandingan $\mathrm{F}$ statistic dengan $\mathrm{F}$ tabel

$\mathrm{HO}$ : Jika F statistic $<\mathrm{F}$ tabel

$\mathrm{Ha}$ : Jika F statistic $>\mathrm{F}$ tabel

Berdasarkan Probabilitas

$\mathrm{HO}$ : Jika nilai Prob (F-statistik) $>\alpha 0,05$

$\mathrm{Ha}$ : Jika nilai Prob (F-statistik) $<\alpha 0,05$

\section{Uji Koefisien Determinasi}

Menjelaskan seberapa jauh kemampuan model regresi dalam menerangkan variasi variabel bebas mempengaruhi variabel terkait. Semakin besar hasil $\mathrm{R}$ - squared akan semakin baik. Nilai $\mathrm{R}$ - squared berada diantara 0 sampai 1 dengan penjelasan 1 ). Nilai $R$ - squared harus berkisar antara 0 sampai 1. 2). Jika nilai $R$ - squared sama dengan 1, berarti naik atau turunnya variabel terikat $(Y)$ 100\%dipengaruhi oleh variabel bebas $(X)$. 3). Jika nilai $R$ - squared sama dengan 0 , berarti tidak ada hubungan sama sekali antara variabel independen terhadap variabel dependen.

\section{Uji t}

Uji t menjelaskan pengaruh variabel bebas secara parsial terhadap variabel terikat. Hipotesis dalam uji $t$ :

Berdasarkan perbandingan $\mathrm{t}$ - statistic dengan $\mathrm{t}$ - tabel

$\mathrm{HO}$ : Jika nilai $\mathrm{t}-$ statistic $<\mathrm{t}$ tabel

$\mathrm{Ha}$ : Jika nilai $\mathrm{t}-$ statistic $>\mathrm{t}$ tabel

Berdasarkan probabilitas 
Ho : Jika nilai Prob $>0,05$

$\mathrm{Ha}$ : Jika nilai Prob $>0,05$

\section{Analisis Regresi Data Panel}

Menurut Eksandy (2018:45), analisis Regresi Data Panel adalah gabungan antara data cross section dan data time serie, dimana unit cross section yang sama diukur pada waktu yang berbeda. Maka dengan kata lain, data panel merupakan data dari beberapa individu (sampel) yang diamati dalam beberapa kurun waktu tertentu. Persamaan Regresi Data Panel adalah sebagai berikut:

$$
Y_{i t}=\beta_{0}+\beta_{1} X_{1 i t}+\beta_{2} X_{2 i t}+\beta_{3} X_{3 i t}+\varepsilon_{i t}
$$

Dimana :

$\mathrm{Y}=$ Variabel Dependen

B_0 = Konstanta

B_ $1,2,3=$ Koefisien Regresi Variabel Independen

$X-1,2,3=$ Variabel Independen

$\mathrm{i}=$ Perusahaan

$\mathrm{t} \quad=$ Waktu

$\varepsilon \quad=$ Residual / Error

\section{HASIL}

\section{Analisis Statistik Deskriptif}

Tabel 1. Analisis Statistik Deskriptif

\begin{tabular}{|c|c|c|c|c|}
\hline \multicolumn{5}{|c|}{$\begin{array}{l}\text { Date: } 11 / 17 / 20 \text { Time: } 19: 20 \\
\text { Sample: } 20172019\end{array}$} \\
\hline & PL & $\mathrm{ROA}$ & ROE & NPM \\
\hline Mean & 4584.628 & 0.204351 & 0.858262 & 0.156837 \\
\hline Median & 1234.500 & 0.012800 & 0.082700 & 0.129800 \\
\hline Maximum & 51139.00 & 11.16330 & 45.74150 & 0.490800 \\
\hline Minimum & 5.000000 & 0.000100 & 0.000800 & 0.000900 \\
\hline
\end{tabular}

Pada tebel 1 dapat dijelaskan bahwa jumlah data (observations) yang digunakan dalam penelitian ini sebanyak 78 data. Nilai mean terbesar dialami oleh variabel PL yaitu 4584.628 sementara NPM memiliki nilai mean terkecil yaitu sebesar 0.156837 . Nilai median terbesar dialami oleh variabel PL 1234.500, sementara variabel ROA memiliki median terkecil yaitu sebesar 0.012800 . Nilai maximum terbesar dialami oleh variabel 51139.00, sementara variabel NPM memiliki maximum terkecil yaitu sebesar 0.490800 . Nilai minimum terbesar dialami oleh variabel PL yaitu sebesar 5.000000, sementara variabel ROA memiliki minimum terkecil yaitu sebesar 0.000100 .

Pemilihan Model Regresi Data Panel 
Tabel 2. Uji Chow

\begin{tabular}{|c|c|c|c|}
\hline Effects Test & Statistic & d.f. & Prob. \\
\hline Cross-section F & 159.074147 & $(25,49)$ & o.00oo \\
\hline Cross-section Chi-square & 343.876413 & 25 & 0.0000 \\
\hline
\end{tabular}

Berdasarkan perhitungan tabel 2, nilai Prob Cross-section $\mathrm{F}$ dan Crosssection Chi square < 0.05 maka dapat disimpulkan bahwa Fixed Effect Model (FEM) lebih layak digunakan dibandingkan Common Effects Model (CEM).

Tabel 3. Uji Hausman

Correlated Random Effects - Hausman Test
Equation: Untitled

Test cross-section random effects

\begin{tabular}{lrrr}
\hline \hline Test Summary & Chi-Sq. Statistic & Chi-Sq. d.f. & Prob. \\
\hline \hline Cross-section random & 7.294965 & 3 & 0.0631 \\
\hline \hline
\end{tabular}

Berdasarkan perhitungan tabel 3 nilai Prob Cross-section random 0.0631 > 0.05 maka dapat disimpulkan bahwa Random Effect Model (REM) lebih layak digunakan dibandingkan Fixed Effect Model (FEM).

Tabel 4. Uji Lagrange Multiplier

\begin{tabular}{|c|c|c|c|}
\hline & \multicolumn{3}{|c|}{ Test Hypothesis } \\
\hline & Cross-section & Time & Both \\
\hline Breusch-Pagan & $\begin{array}{l}67.43477 \\
(0.0000)\end{array}$ & $\begin{array}{l}0.860549 \\
(0.3536)\end{array}$ & $\begin{array}{l}68.29532 \\
\text { (0.0000) }\end{array}$ \\
\hline
\end{tabular}

Berdasarkan perhitungan tabel 4 nilai Probilitas Cross-section Breuschpagan $0.000<0.05$ Maka dapat disimpulkan bahwa Random Effect Model (REM) lebih layak digunakan dibandingkan Common Effects Model (CEM).

Tabel 5. Kesimpulan Model

\begin{tabular}{|c|c|c|}
\hline NoMetode & Pengujian & Hasil \\
\hline 1Uji Chow & CEM vs FEM & FEM \\
\hline 2Uji Hausman & REM vs FEM & REM \\
\hline $\begin{array}{l}\text { 3Uji Langrage } \\
\text { Multiplier }\end{array}$ & CEM vs REM & REM \\
\hline
\end{tabular}

Berdasarkan hasil ketiga pengujian yang sudah dilakukan maka dapat disimpulkan bahwa Model Regresi Data Panel yang akan digunakan dalam uji hipotesis dan persamaan regresi Data Panel adalah model Random Effect Model (REM). 
Uji Hipotesis

Tabel 6. Random Effect Model

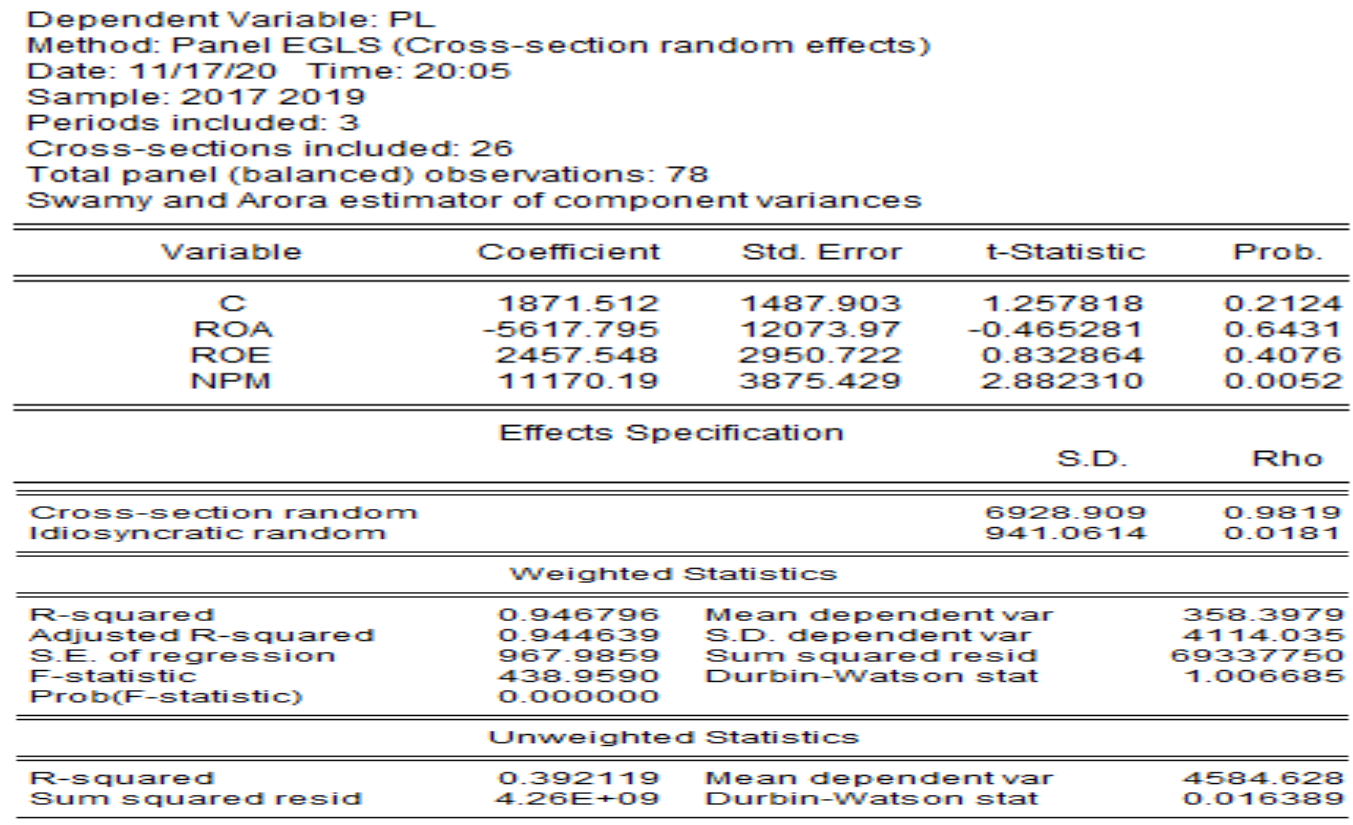

Pada tabel 6 diatas menunjukkan bahwa nilai F-Statistic sebesar 438.9590, sementara $F$ table dengan tingkat $5 \%$, df1 $(\mathrm{k}-1)=3$ dan df2 (n$k)=74$ didapat nilai $F$ Tabel sebesar 2.73. dengan demikian F Statistic (438.9590) > F Tabel (2.73) dan nilai prob (F-Statistic) $0.000000<0.05$ maka dapat disimpulkan bahwa $\mathrm{Ha}$ diterima, maka dengan demikian dapat disimpulkan bahwa variabel-variabel independen dalam penelitian ini yang terdiri dari ROA, ROE dan NPM secara bersama sama memiliki pengaruh terhadap PL.

Nilai t-Statistic ROA sebesar $(-0.465281)$, sementara t Tabel dengan tingat $\alpha=5 \%$, df $(n-k)=74$ didapat nilai $t$ Tabel sebesar 1.99254, dengan demikian t- statistic ROA $(-0.465281)<t$ Tabel (1.99254) dan nilai prob $0.6431>0.05$ maka dapat disimpulkan bahwa variabel ROA dalam penelitian ini tidak memiliki pengaruh terhadap PL.

Nilai t-Statistic ROE sebesar 0.832864 , sementara t Tabel dengan tingat a $=5 \%$, df $(n-k)=74$ didapat nilai $t$ Tabel sebesar 1.99254, dengan demikian t- statistic ROE (0.832864) < t Tabel (1.99254) dan nilai prob $0.4076>0.05$ maka dapat disimpulkan bahwa variabel ROE dalam penelitian ini tidak memiliki pengaruh terhadap PL.

Nilai t-Statistic NPM sebesar 2.882310, sementara t Tabel dengan tingat $\alpha$ $=5 \%$, df $(n-k)=74$ didapat nilai $t$ Tabel sebesar 1.99254, dengan demikian t- statistic NPM (2.882310) > t Tabel (1.99254) dan nilai prob $0.0052<0.05$ maka dapat disimpulkan bahwa variabel NPM dalam penelitian ini memiliki pengaruh terhadap PL. 


\section{PEMBAHASAN}

Berdasarkan Uji $t$ (Parsial) Pengujian hipotesis ROA terhadap pertumbuhan laba, menghasilkan perhitungan t- statistic ROA (-0.465281) $<\mathrm{t}$ Tabel (1.99254) dan nilai prob $0.6431>0.05$ dengan demikian $\mathrm{HO}$ diterima dan $\mathrm{Ha}$ ditolak, hal ini berarti ROA tidak mempunyai pengaruh terhadap Pertumbuhan Laba.

Pengujian Hipotesis ROE terhadap Pertumbuhan laba menghasilkan perhitungan t- statistic ROE $(0.832864)<\mathrm{t}$ Tabel (1.99254) dan nilai prob $0.4076>0.05$ dengan demikian $\mathrm{HO}$ diterima dan $\mathrm{Ha}$ ditolak, hal ini berarti ROE tidak mempunyai pengaruh terhadap Pertumbuhan Laba.

Pengujian Hipotesis NPM terhadap Pertumbuhan laba menghasilkan hasil perhitungan demikian t- statistic NPM (2.882310) > t Tabel (1.99254) dan nilai prob $0.0052<0.05$ dengan demikian Ha diterima dan $\mathrm{HO}$ ditolak, hal ini berarti NPM mempunyai pengaruh terhadap Pertumbuhan Laba.

\section{KESIMPULAN}

Berdasarkan rumusan masalah dari hasil penelitian yang telah diuraikan, kesimpulan dari penelitian ini adalah ROA tidak berpengaruh terhadap pertumbuhan laba. ROE tidak berpengaruh terhadap pertumbuhan laba. NPM mempunyai pengaruh terhadap pertumbuhan laba.

Dari penelitian yang sudah dijelaskan diatas diharapkan dapat digunakan sebagai bahan informasi untuk penelitian lebih lanjut dimasa yang akan datang. Penelitian selanjutnya disarankan untuk menambah variabel penelitian lain yang lebih luas cakupannya dan dapat dipahami bahwa masih banyak faktor-faktor lain yang dapat digunakan sebagai indikator yang mampu mempengaruhi pertumbuhan laba suatu perusahaan. Selain itu, menggunakan waktu periode yang lebih lama sehingga mendapatkan kelengkapan data yang akurat dan objek pada penelitian selanjutnya sebaiknya menggunakan objek yang lebih luas, tidak hanya perusahaan Perbankan saja tetapi perusahaan lainnya yang terdaftar di BEl.

\section{DAFTAR PUSTAKA}

Arry Eksandy. (2018). Accounting and Management Research Methods. (Mohamad Zulman Hakim, Ed.). Tangerang: FEB UMT.

Aris, \& Jalari, M. (2017). Pengaruh Rasio Keuangan Terhadap Pertumbuhan Laba Pada Perusahaan Properti Dan Real Estate Yang Terdaftar Di Bursa Efek Indonesia, 2(2), 1-23. Retrieved from http://journal.amikomsolo.ac.id/index.php/ekacida/article/view/66

YAHYA, A. D. (2018). Volume XI, Nomor 1, Desember 2018 Yahya. Pengaruh Rasio Keuangan Terhadap Pertumbuhan Laba Pada Pt Krakatau Steel (Persero)Tbk Periode 2010-2014, XI, 147-158.

Febrianty. (2017). Pengaruh Rasio Keuangan Terhadap Pertumbuhan Laba Perusahaan Perbankan A. PENDAHULUAN Stabilisasi perekonomian ditentukan oleh banyak faktor baik fundamental 
maupun teknis, salah satu penggerak perekonomian di Indonesia adalah sektor perbankan yang memp, 12(2).

Sari, M. P., \& Idayati, F. (2019). Pengaruh Rasio Keuangan Terhadap Harga Saham Sektor Properti dan Real Estate pada Bursa Efek Indonesia. Jurnal IImu Dan Riset Akuntansi, 8, 5.

Ravasadewa, R. P. (2018). Pengaruh Rasio Keuangan Terhadap Pertumbuhan Laba Pada Perusahaan Batubara Di Bursa Efek Indonesia. Jurnal IImu Dan Riset Manajemen E-ISSN: 2461-0593, 7, $1-18$.

Safitri, A. M., \& Mukaram, M. (2018). Pengaruh ROA, ROE, dan NPM Terhadap Pertumbuhan Laba Pada Perusahaan Sektor Industri Barang Konsumsi Yang Terdaftar di Bursa Efek Indonesia. Jurnal Riset Bisnis Dan Investasi, 4(1), 25. https://doi.org/10.35697/jrbi.v4i1.990

Agustininingsih, T., Soebroto, N. W., \& Rakim, A. A. (2019). PENGARUH DEBT TO EQUITY RATIO, NET PROFIT MARGIN, DAN RETURN ON EQUITY TERHADAP PERTUMBUHAN LABA (Studi Kasus pada Bank BUKU IV tahun 2009-2018), (8), 1-10.

Fatihah, A. (2018). Pengaruh Kinerja Keuangan Terhadap Pertumbuhan Laba Pada Perdagangan Eceran. Jurnal IImu Dan Riset Manajemen (JIRM), 7(e-ISSN :2461-0593).

Mahar Mardjono, Asdar Djamereng, A. P. (2011). Pengaruh Kinerja Keuangan Terhadap Pertumbuhan Laba pada Perusahaan Manufaktur Sub Sektor Industri Semen yang Terdaftar di BEI, 1(1), $1-13$.

Wairooy, M. A. (2019). PENGARUH KINERJA KEUANGAN TERHADAP PERTUMBUHAN LABA PADA PT. SEMEN TONASA (Persero) DI KABUPATEN PANGKEP. Jurnal Ekonomi Balance, 15(2), 52-68. https://doi.org/10.26618/jeb.v15i2.2185

Yanti, N. S. P. (2017). Dampak Kinerja Keuangan Terhadap Pertumbuhan Laba (Studi Kasus pada Perusahaan Makanan dan Minuman yang Terdaftar di Bursa Efek Indonesia Tahun 2010-2016). Jurnal Ekonomi \& Bisnis Dharma Andalas, 19(2), 220-234.

Sugawara, E., \& Nikaido, H. (2014). Pengaruh Kinerja Keuangan Terhadap Pertumbuhan Laba Pada Perusahaan Food and Beverages. Antimicrobial Agents and Chemotherapy, 58(12), 72507257.Retrievedfrom 